\title{
Empresariando o Trabalho: Os Agentes Econômicos da Intermediação de Empregos, esses Ilustres Desconhecidos*
}

\author{
Nadya Araujo Guimarães
}

\begin{abstract}
literatura da sociologia do trabalho tem sido relativamente farta A em estudos sobre os ambientes de trabalho, com ênfase especial nas formas como neles são tecidas as relações entre trabalhadores e gerentes. Nesse sentido, essa literatura emulou tanto com a reflexão da sociologia da empresa quanto com a do emprego, domínios avizinhados, mas de fato tão reciprocamente irredutíveis quanto socialmente enraizados em suas linhagens intelectuais e em seus ambientes acadêmicos específicos.
\end{abstract}

\footnotetext{
* Este texto é uma versão revista de uma comunicação que tive o privilégio de ver discutida em duas oportunidades. Inicialmente na mesa-redonda O Mundo do Trabalho e o Empresariado, no V Workshop Empresa, Empresários e Sociedade: O Mundo Empresarial e a Questão Social (Pontifícia Universidade Católica do Rio Grande do Sul - PUC-RS, Porto Alegre, 2-5 de maio de 2006); e posteriormente na mesa-redonda As Novas Formas da Relação de Emprego e das Condições de Trabalho: Rumo à Precarização?, no Colóquio Internacional Novas Formas do Trabalho e do Desemprego: Brasil, Japão e França numa Perspectiva Comparada (Universidade de São Paulo - USP, 11-12 de setembro de 2006). O desenvolvimento das idéias aqui expostas não teria sido possível sem diversos tipos de apoio que gostaria de registrar em sinal de agradecimento: o suporte financeiro do Conselho Nacional de Desenvolvimento Científico e Tecnológico-CNPq e da Fundação de Amparo à Pesquisa do Estado de São Paulo - FAPESP; o suporte institucional do Departamento de Sociologia da USP e do Centro Brasileiro de Análise e Planejamento Cebrap, unidos no Centro de Estudos da Metrópole - CEM; o diálogo intelectual em minha equipe de pesquisa, à qual devo idéias, sugestões e correções ao argumento preliminar que apresentei para discussão em nosso seminário interno; e finalmente, os pareceristas da $D A D O S$, com suas pertinentes observações. Claro está que os equívocos porventura contidos nas formulações aqui avançadas são de minha inteira e solitária responsabilidade.
}

DADOS - Revista de Ciências Sociais, Rio de Janeiro, Vol. 51, n²2, 2008, pp. 275 a 311. 
Trabalho, emprego e empresa constituíram, assim, campos temáticos independentes, remetendo, cada um deles, a dimensões próprias da vida social, a saber: o processo de trabalho, o mercado de trabalho e a firma. Todas elas dimensões pautadas pelo foco no comportamento institucionalizado em torno de regras de tipo mercantil-capitalista, conquanto tratando mercados particulares, como o mercado de trabalho e o de produtos.

Ao passo que o primeiro - o mercado de trabalho - foi tradicionalmente descrito como o lócus por excelência do estabelecimento das trocas entre compradores e vendedores de força de trabalho, o segundo era descrito como o âmbito da interação entre compradores e vendedores de bens e serviços. Enquanto o mercado de trabalho era o espaço em que contratante de trabalho (organizado empresarialmente como firma) e vendedor de trabalho (figurado como o indivíduo "livre e despossuído") se defrontavam em uma sorte de enfrentamento entre Golias e Davi, o mercado de produtos supunha relacionamentos mais diversos, envolvendo trocas entre firmas, assim como entre estas e os indivíduos.

Competição e alianças logo atraíram a atenção da literatura da sociologia da firma. Desse modo, o mercado de bens e serviços cedo passou a ser tratado em toda a complexidade que o caracterizava. Complexidade, de resto, imperiosa, seja porque os limites entre manufatura e serviços passaram a se mostrar mais tênues, seja porque as estratégias gerenciais tiveram de ser crescentemente entendidas, em toda a sua complexidade, como estratégias de produção, de gestão do trabalho, mas sobretudo de gestão de negócios, o que requeria ter também em conta a gestão das imagens de marcas e de consumo.

Já o mercado de trabalho seguiu por muito tempo sendo um âmbito estudado mais por seus resultados e configurações (para usar um termo caro aos economistas, por sua "estrutura") do que pelos processos que nele tinham lugar. Tais processos permaneciam pouco percebidos em sua complexidade social responsável por dotar as relações de trabalho que ali se pactuavam de particular estruturação em formas institucionalizadas.

A insuficiência desse olhar não deixaria, mais cedo ou mais tarde, de se fazer sentir. Restavam por aclarar pelo menos dois aspectos cruciais a um olhar sociológico: 1) por que, em face de uma pluralidade de possibilidades de troca entre agentes, uma, e apenas uma, se tornava efetiva ${ }^{1}$ ?; 2 ) quais os mecanismos mobilizados pelos agentes em seu esfor- 
ço para transformar a infinidade de trocas potenciais em um resultado final em que apenas uma dessas trocas se consumava? O mercado por onde circulava a "mercadoria força de trabalho" por certo não estaria livre do desafio analítico aberto por esse tipo de abordagem.

Os economistas habitualmente respondiam a esses desafios recorrendo a funções de preço e de produtividade e ao cruzamento entre ambas, cuja condição de possibilidade estava ancorada no suposto da racionalidade da conduta dos agentes econômicos. Assim, o xis do problema estaria na convergência de interesses em torno do preço pelo qual um trabalhador qualquer aceitaria vender sua capacidade de trabalho (ou comprá-la, se considerarmos o ponto de vista do empresário) dada a produtividade suposta (encarnada em um certo quantum de capital humano) que possuiria (ou que necessitaria adquirir para incorporar a seu negócio, tomando ainda o prisma do empresário que recruta).

Se as características das condições da concorrência perfeita, como transparência, permeabilidade, homogeneidade, mobilidade, entre outras, têm sido postas em questão pela moderna sociologia dos mercados, por certo elas são de duvidosa prevalência e de escassa aplicação imediata, em especial nos mercados por onde circula o trabalho (White, 1981; Granovetter, 1985; 1991; Garcia-Parpet, 1986; Swedberg, 1994; Fligstein, 1996; Steiner, 1999; 2004). Sabemos que são socialmente complexos os mecanismos pelos quais se entrecruzam a oferta de trabalho e a procura de trabalhadores, e que tais mecanismos passam por instâncias nãomercantis, tal como demonstrado por Granovetter $(1973 ; 1974)$ a propósito do papel das redes sociais.

Mais ainda: dificilmente o funcionamento do mercado de trabalho poderia ser adequadamente descrito pela imagem da díade formada pelo empresário que recruta e o trabalhador que se oferece no mercado. Esse funcionamento requer ser representado por um modelo mais complexo, já que diferentes formas institucionais hoje nele se apresentam. Tais formas, longe de convergirem apenas para os extremos dessa relação de força em que estariam o contratante e o contratado, distribuem-se por várias linhas de tensão que podem ser mais bem representadas como convergindo para as extremidades de outra figura, a do triângulo.

Qual seria, então, o terceiro elemento a intervir na antiga linha de forças que antepunha nossos Davi e Golias? O intermediador. É ele que forja a dinâmica de um "novo" mercado que se constitui no interior do 
próprio mercado de trabalho - o "mercado de intermediação das oportunidades de trabalho". Desse modo, o tema dos serviços (de intermediação) é posto no coração do entendimento dessa mercadoria especial, a "força de trabalho", que teoricamente fora tratada sobretudo do prisma de seu "consumo produtivo", para usar a categoria de Marx (1985).

Neste artigo, pretendo evidenciar, à luz do caso do Brasil e, em especial, de dados para a Região Metropolitana de São Paulo², como se constitui e opera essa complexa relação de forças não mais bipolar, mas tripolar. Pretendo sublinhar, no desenvolvimento de meu argumento, como múltiplas formas institucionais convergem para os três grandes pólos que descrevem hoje a organização do mercado de trabalho: o pólo dos agentes que demandam emprego (os trabalhadores, não necessariamente desempregados, ainda que majoritariamente o estejam); o pólo das firmas que se utilizarão do trabalho a ser recrutado no mercado (que não necessariamente são as firmas contratantes); e o pólo dos agentes que disponibilizam vagas no mercado, tornando-as visíveis, transparentes, para os demandantes, mas que também fazem o caminho de volta, triando e locando trabalhadores potenciais (agentes que não necessariamente são firmas nem mesmo simples recrutadores).

Dependendo de quem demanda trabalho e de que tipo de vaga se oferta, esse triângulo pode se configurar em mecanismos e meios de encontro entre demandantes e ofertantes tão variados quanto a moderna procura virtual por trabalho que circula em sites na internet, ou quanto a veiculação de oportunidades por meio de precários anúncios colados ao corpo de "homens-placa". Afinal, os intermediadores são, eles próprios, empregadores e tecem relações de trabalho complexas e muito diversas, que cabem ser desveladas para melhor se entender como, entre as múltiplas "trocas potenciais", apenas uma delas se converte em "troca efetiva", para usar os termos do argumento weberiano.

Enfim, busco tratar do estatuto analítico que devemos outorgar aos agentes econômicos da intermediação de empregos, aí compreendida a reflexão sobre os mecanismos extra-econômicos que pautam sua conduta. Fazê-lo é condição imperiosa para bem interpretar as formas pelas quais firmas e indivíduos se relacionam nos mercados contemporâneos de trabalho. Mercados hoje tão fortemente impactados pela dissolução de antigas normas do trabalho - de maior ou menor difusão real, 
mas de elevada eficácia simbólica - e pela crescente flexibilização das relações sociais e contratuais envolvidas na negociação da cessão/aquisição do tempo de trabalho.

No entanto, fazê-lo é particularmente interessante quando refletimos à luz de um caso como o do Brasil, em que a flexibilidade de contratos não se constitui, como no figurino das expectativas teóricas mais usuais, em um resultado da transição que ultrapassa um modo fordista de regulação do trabalho (Boyer, 1988; Boyer e Durand, 1997). Longe disso. Entre nós, certas características estruturais propiciaram um padrão de flexibilidade numérica que tem estado na base dos principais movimentos de nossa economia. Dentre tais características, destacaria o peso das relações não formalizadas e a diferença não-desprezível existente entre os nossos mercados regionais de trabalho, para não mencionar os baixos níveis de qualificação dos trabalhadores e o escasso poder de fogo da organização sindical para fazer face à intensa rotação nos empregos, com destaque para o período autoritário, quando se extingue o instituto da estabilidade e são regulamentadas as novas regras para rompimento de contratos de trabalho. Entre nós, a produção em massa parece ter aportado livre das contrapartidas sociais que caracterizaram o fordismo alhures, tais como uma política de salários, que fazia do trabalhador um consumidor potencial, e uma política de relações de trabalho, que fazia do sindicato o interlocutor capaz de representar interesses coletivos.

Por último, mas não menos importante, cabe ressaltar que, se a ação direta e a proteção do Estado (que hoje diríamos afirmativa, porque compensadora de desvantagens de partida) foram parteiras do desenvolvimento econômico e de benfeitorias ao empresariado nacional, foram também madrastas na parcimônia com que concederam benefícios e definiram critérios de elegibilidade para triar aqueles a serem incluídos no que seria um sistema público de proteção aos trabalhadores. Sem ele - pude documentá-lo em outras oportunidades (Guimarães et alii, 2004; Guimarães, 2006; Demazière, Guimarães e Sugita, 2006) - a produção da sobrevivência se torna um empreendimento complexo, no qual o domínio do privado ganha proeminência como celeiro das soluções. Estas demandam recurso a redes pessoais (sobretudo familiares), a estratégias individuais e à "viração" sistemática, que mitigam os efeitos de trajetórias ocupacionais erráticas e respondem a um regime de welfare (Galie e Paugam, 2000) restrito em seus benefícios e em sua capacidade de inclusão, além de muito recente em internalizar ins- 
titutos internacionalmente consagrados de proteção, como o seguro-desemprego, a assistência ao trabalhador em sua busca de emprego ou o apoio a suas necessidades de requalificação.

Quando o desemprego provê a notável massa de demandantes de trabalho que passa a se concentrar em grandes metrópoles como São Paulo, quando as firmas enxugam funcionários e externalizam funções, e quando se carece de um sistema público de emprego e de proteção social ao trabalho solidamente institucionalizado, triar multidões para uma nova vaga aberta torna-se uma tarefa desproporcionalmente onerosa, seja para as empresas que contratarão, seja para os trabalhadores que almejam o posto. Nesse vácuo, os agentes privados da intermediação de empregos preenchem um espaço estratégico - de novo, para empresas e trabalhadores -, que se mostra também economicamente viável para ser explorado enquanto negócio, mesmo em um contexto social pobre e desigual como o brasileiro.

Como tal mercado se estrutura e quem são os agentes econômicos da intermediação de oportunidades de trabalho, esses ilustres desconhecidos para a sociologia brasileira do trabalho, são o objeto de interesse das partes que seguem. Na primeira, dialogo com a literatura internacional, já razoavelmente significativa; na segunda, retraço as particularidades da construção institucional desse mercado no caso brasileiro; na terceira, apuro ainda mais o foco, buscando entender como, em um espaço particular, tal construção se enraíza e quão mais diversos ainda podem se mostrar os mecanismos e os atores envolvidos no processo de fazer circular (e obter) informações sobre as oportunidades ocupacionais que se abrem aos indivíduos em um mercado de trabalho como o da Região Metropolitana de São Paulo, sujeito a intensa competição entre os demandantes de emprego.

\section{DIALOGANDO COM A LITERATURA: OS INTERMEDIÁRIOS E AS REDES SOCIAIS NO AGENCIAMENTO DO EMPREGO}

A constituição de instituições de intermediação e, notadamente, daquelas vocacionadas ao chamado "negócio do trabalho temporário" tem sido crescentemente tratada por uma literatura ávida por descrever o papel de tais intermediários na (re)inserção ocupacional. Se essa literatura não chega a ser abundante, tampouco deixa de ser significativa. Análises recentes surgem nas mais diferentes latitudes: Estados Unidos (Peck e Theodore, 1999; Benner, Leete e Pastor, 2007), Europa 
(Kartchevsky e Caire, 2000; Forde, 2001; Beynon et alii, 2002; Gray, 2002; Bergström e Storrie, 2003; Koene e Purcell, 2004) e países da América Latina (Echeverría, 2001), inclusive o Brasil (Pamplona, 2003; Guimarães, 2004; Consoni e Bessa, 2007).

Em todos esses estudos, destaca-se uma nova figura que surge no mercado de trabalho organizando a intermediação entre, de um lado, necessidades cada vez mais flexíveis (em termos numéricos e funcionais) por parte das empresas e, de outro, a busca de novas oportunidades ocupacionais por parte de trabalhadores que, ou foram desligados depois de contratos duradouros em funções agora reestruturadas, ou são (re)ingressantes no mercado de trabalho. Trata-se de empresas organizadas com o fito de não apenas fazer circular informações sobre oportunidades de trabalho mas também agenciar trabalhadores, ou seja, prover pessoal para outras firmas, tanto intermediando trabalhadores para contratos a serem firmados com outrem quanto contratando diretamente para uso por múltiplos demandantes finais. Sendo o outro lado da moeda do movimento de reestruturação das firmas, sua presença no mercado de trabalho é tão mais forte quanto mais intensa e perceptível se mostra tal reestruturação. Nesse sentido, não são apenas, ou necessariamente, agências de emprego, já que têm um espectro de atuação bem mais amplo no que tange à intermediação de mão-de-obra. Parcela significativa é formada por organizações que assumem a condição de empregadores daqueles demandantes cuja colocação agenciam com respeito a um terceiro (Echeverría, 2001).

Longe de se reduzirem à imagem simplificada e estereotipada que vulgarmente mantemos com respeito ao trabalho temporário, chama a atenção, na literatura, sua diversidade e, mais que isso, certa polarização que caracterizaria tais intermediadores de empregos em mercados sob intensa reestruturação das firmas e, logo, sob grande volatilidade no que concerne às oportunidades de trabalho. Peck e Theodore (1999), analisando o caso de Chicago nos anos 1990, metrópole em que mais crescia o trabalho temporário nos Estados Unidos no momento de seu estudo, identificaram dois segmentos bastante distintos. De um lado aquele que, a juízo dos autores, refletiria uma espécie de "via alta" (high road) no processo de reestruturação econômica regional, sendo caracterizado por empresas de grande porte que serviam a uma gama crescente de demandantes, fazendo-o de maneira cada vez mais profissional e estabelecendo relações contratuais progressivamente mais estáveis com seus clientes. Por isso, tenderiam a atender a uma demanda 
por trabalhadores de maior qualificação, o que as obrigaria a atentar para (e a desenvolver) suas próprias estratégias de recursos humanos. De outro, haveria um segundo segmento de empresas de agenciamento e locação de trabalho temporário. Essas, ao contrário das primeiras, tipificariam uma sorte de "via baixa" (low road). Seriam sobretudo agências pequenas, de proprietários locais e em cadeias também locais ou regionais. Estariam voltadas para atender a mercados sensíveis ao valor dos salários e dispostos a recrutar trabalhadores de baixa qualificação, notadamente nos chamados segmentos leves (embalagem, transporte de materiais etc.). Seriam especializadas, portanto, no segmento mais pobre do mercado (ibidem:138-139).

Diversidade foi também o que encontraram Benner, Leete e Pastor (2007) em estudo no qual foram analisadas duas outras regiões dos Estados Unidos: uma no Meio-Oeste, Milwaukee ${ }^{3}$, e outra na Califórnia, o Vale do Silício, situações igualmente marcadas por intensa volatilidade econômica e amplo uso de intermediários do trabalho dito flexível.

Já Koene e Purcell (2004) foram adiante explorando um argumento instigante à luz de um estudo comparativo que envolveu Holanda e Reino Unido, dois dos maiores mercados de intermediação privada na Europa. Esses autores estudaram a modalidade de gestão nessas complexas relações tripartites de contrato e de uso do trabalho. A forma de atuação dos intermediários privados nesses mercados levou-os a reconhecer não apenas a heterogeneidade interna a esse segmento mas também a sugerir um paradoxo em seu padrão de atuação. De um lado a proliferação do trabalho temporário ocorre, corroborando importante literatura, em um contexto de fragilização de contratos, de crescente precarização dos empregos e de notável insegurança por parte dos trabalhadores sujeitos ao desemprego recorrente (ver, por exemplo, o argumento eloqüente de Beck e Beck-Gernsheim, 2003). De outro, Koene e Purcell (2004) encontraram que as agências tenderiam, simultânea e paradoxalmente, a alimentar a estabilidade dos vínculos que constituíam, quer seja com as empresas demandantes de seus serviços, quer seja com os trabalhadores temporários que alocavam, uma vez que estes levavam ao mercado o nome e a imagem do empreendimento que intermediara sua colocação. Uma tensão entre precarização e fidelização marcaria, assim, o novo e paradoxal mundo do trabalho temporário.

A complexidade do debate sobre o sistema de intermediação se mostra ainda mais desafiadora quando nela incluímos outras realidades em 
que, pela configuração dos sistemas de emprego e pela natureza dos regimes de proteção, o Estado desempenha um papel também importante no movimento de colocação de trabalhadores em oportunidades ocupacionais. Esse é o caso da França, onde a força do sistema público de proteção cruza todo o longo período fordista, chegando até os nossos dias. A cobertura e a amplitude dos benefícios que concede, mesmo em um contexto de intensificação do desemprego de longa duração, são notáveis em face de outras sociedades capitalistas modernas, fazendo do sistema público francês de intermediação de empregos um ator central nas estratégias individuais que lançam mão das instituições do mercado de trabalho na busca de saída do desemprego. Nessas condições, abrem-se outras indagações analíticas igualmente importantes, a principal delas relativa à especificidade de um sistema público de intermediação de oportunidades, notadamente na maneira como ele recebe e tria o indivíduo que busca trabalho (ver Benarrosh, 2000) ${ }^{4}$.

Conquanto se trate de um fenômeno visível nos vários quadrantes e em crescente expansão, são consideráveis suas variações entre contextos sociais tanto no que concerne às modalidades da intermediação quanto à seletividade social com que o trabalho temporário se distribui entre grupos específicos, ou ainda aos modos de gestão dessas novas relações de trabalho contratado mediante intermediadores.

No entanto, o horizonte de indagações é ainda mais largo. Isso porque sabemos que o acesso a oportunidades de trabalho com freqüência também se resolve por meio de mecanismos que escapam à racionalidade das instituições especializadas do mercado, fundando-se em outra razão, já que ancorados na estrutura e no funcionamento de redes sociais tecidas no curso da vida cotidiana. Nesse terreno, o debate sobre oportunidades no trabalho, em particular sobre a circulação de informações no mercado de trabalho, é grandemente devedor das formulações de Granovetter (1973; 1974; 1985; 1991).

Granovetter, seguindo pistas tão diversas quanto as de Polanyi (2000) [1944] e White (1970; 1981), sugeriu - e documentou empiricamente que a criação e a evolução de um mercado (aí compreendido o mercado de trabalho) dependeriam de certo número de condições sociais e políticas que contribuiriam igualmente para seu funcionamento, o que Swedberg (1994) posteriormente denominaria "estrutura social do mercado". No caso das oportunidades ocupacionais, ou da procura de trabalho, por exemplo, seriam considerados os contatos a partir dos 
quais as pessoas se tornavam sabedoras da informação ocupacional pertinente mesmo quando não estivessem disponíveis no mercado, ou seja, em busca de uma ocupação. Assim, ao entrevistar chefias e quadros mais altamente qualificados em seu famoso estudo, Granovetter (1974) se deu conta de que o encontro entre demandantes e ofertantes de trabalho se realizava por meio de três diferentes mecanismos: procedimentos impessoais (anúncios e agências de emprego); candidaturas espontâneas (via prospecção direta junto aos empregadores); e contatos pessoais. Pouco mais do que cinco em cada dez indivíduos investigados por ele reconheciam nos contatos pessoais, e não nos mecanismos mercantis, a grande via para localizar oportunidades ocupacionais.

Convergindo com esse achado, em survey realizado em 2001, em São Paulo, encontrei nada menos do que sete em cada dez indivíduos declarando que as informações obtidas junto a familiares, amigos e conhecidos constituíam a forma mais freqüente de buscar trabalho. Mais ainda: para mais da metade dos entrevistados, essa foi a forma eficaz que lhes permitiu obter o último emprego. Embora o peso dos mecanismos institucionais e dos circuitos impessoais se mostrasse bem maior em Paris e em Tóquio (duas outras metrópoles igualmente incluídas nesse estudo), a importância dos contatos pessoais não era descartável nessas cidades, confirmando o argumento dos socioeconomistas no sentido da importância do enraizamento social das formas mercantis. Entretanto, era em São Paulo que os contatos pessoais adquiriam notável relevância (Guimarães et alii, 2004), e não apenas os chamados "elos fracos", como encontrados antes por Granovetter $(1973 ; 1974)$ ou por Degenne e Forsé (1994), mas também os circuitos de veiculação da informação marcados por sua maior proximidade com respeito ao indivíduo em busca de trabalho (Guimarães e Picanço, 2007).

Qual é a importância desses achados para estimular a reflexão sobre a operação dos mercados de trabalho? Eles sugerem que a articulação entre ofertantes e demandantes não se realiza por mecanismos unicamente mercantis de difusão da informação, mas pode ser também um subproduto de outras relações sociais que não têm uma dimensão mercantil. Nesse sentido, o funcionamento do mercado de trabalho, assim como de outros mercados, demanda que outras estruturas sociais subjacentes sejam examinadas para que se compreendam as formas de transmissão de oportunidades. Esse é um processo que não se resume aos mecanismos usuais de coordenação mercantil via sistema de pre- 
ços; no caso, o preço pelo qual se admite trabalhar ou, visto de outro ângulo, o preço pelo qual se aceita recrutar um trabalhador.

Os achados até aqui referidos apontam que instituições do mercado e redes sociais são mecanismos complementares para a promoção do encontro entre ofertantes e demandantes de trabalho na busca por resolver o enigma weberiano de como uma multiplicidade de possíveis relações de troca acaba por se converter em uma única, que se efetiva no final como resultado. Entretanto, esses estudos também permitem aventar a hipótese de que tal complementaridade não se faz, seja de modo alternativo, em um modelo soma-zero, seja pela especialização de alguns agentes em um ou outro desses mecanismos (assumindo, por exemplo, que empresas usuárias recorreriam dominantemente às instituições do mercado de trabalho, como os intermediadores, enquanto os demandantes mobilizariam sobretudo seu capital de contatos). $\mathrm{O}$ recurso às redes é um mecanismo importante para se entender a conduta das empresas ao recrutarem diretamente, tal como Granovetter (1974) mostrou, para ocupações qualificadas e de mando no coração do capitalismo, não sendo apenas o modo como demandantes de trabalho perscrutam o mercado. No entanto, redes são decisivas também para se entender a forma como opera o próprio mercado de intermediação, ou seja, como os intermediários nele se localizam e se articulam entre si, com empresas usuárias que os contratam e com demandantes de emprego que a eles acorrem.

\section{MERCADO DE INTERMEDIAÇÃO DE EMPREGOS: UMA CONSTRUÇÃO INSTITUCIONAL}

Por certo, dada a natureza deste artigo, a retomada de autores até aqui empreendida foi rápida e, por isso mesmo, fortemente seletiva. Não obstante, ela nos dá fôlego para seguirmos refletindo com respeito a um aspecto diante do qual a literatura acadêmica ainda empreende seus primeiros esforços: qual é a especificidade atual do mercado de trabalho quando o figuramos do ponto de vista do "mercado de intermediação de oportunidades de emprego" que nele está contido e que se torna crescentemente robusto e diversificado? Em outros termos, como delimitar os contornos do mercado de intermediação se entendermos que se trata apenas de um segmento do mercado de trabalho e que a ele não se reduz, por mais que tenha no intermediador uma peça importante de seu funcionamento contemporâneo? 
Começaria dizendo que, como em todo mercado, ao mercado de intermediação de oportunidades de emprego também acorrem demandantes e ofertantes; no caso, demandantes e ofertantes de força de trabalho. Como em todo mercado, também nele tal circulação está institucionalizada e é normativamente regulada ${ }^{5}$. Sendo assim, qual seria, então, a novidade do mercado de intermediação de empregos? A partir do momento em que ele se institucionaliza, a circulação da mercadoria "força de trabalho" passa a estar mediada por um terceiro, um novo agente econômico - o intermediário -, que não se confunde nem com o comprador nem com o vendedor de força de trabalho, sendo especializado em promover a circulação desta última.

A existência do intermediário de força de trabalho, institucionalizado e operando em larga escala, constitui um evento recente na história dos mercados capitalistas do trabalho. Sua presença evidencia o paradoxo de uma situação na qual o aumento no número de agentes na transação de uma mercadoria pode ser um fator que racionaliza sua circulação, reduzindo custos para vendedores e compradores. Por outro lado, como veremos adiante, a multiplicação desses agentes se fez à condição de se vencer uma construção simbólica de grande vigência, a de que o trabalho não poderia ser pensado como uma mercadoria qualquer, argumento que esteve na base da nova ordem internacional erigida no âmbito do trabalho no pós-guerra.

Pensando, então, de modo simples e abstrato, três atores econômicos configurariam o mercado de intermediação de empregos: o vendedor de força de trabalho, o comprador de força de trabalho (agentes básicos em um mercado de trabalho) e o intermediário na venda de força de trabalho. Quem seria este último?

No contexto atual, o intermediário pode assumir duas formas institucionais básicas, se continuarmos pensando de modo ainda ideal-típico: agência de empregos ou empresa de trabalho temporário. No caso da primeira, faz circular apenas a informação sobre vagas ofertadas e/ou sobre demandantes em busca de trabalho. Seu negócio seria, então, reduzir a opacidade no mercado, tornando mais transparentes as iniciativas dos dois agentes básicos pelo melhor acesso à informação. No caso da segunda, realiza não apenas a circulação da informação sobre oportunidades ocupacionais mas também a circulação da própria força de trabalho mediante o agenciamento de trabalhadores, 
via contratação direta, para atividades a serem desenvolvidas na empresa usuária.

É evidente que as fronteiras entre essas duas situações-tipo são tão mais tênues quanto mais heterogêneo for o mercado de trabalho e quanto mais complexas forem essas empresas de intermediação. Sendo assim, ao observarmos as formas realmente existentes, há muito mais variantes, surgindo um caleidoscópio de situações que se diferenciam segundo os tipos de demandante e de vaga intermediados.

Ganhos de escala - conseqüentes à consolidação do negócio - são o caminho virtuoso para realizar tal conjugação de linhas de atuação. Desse modo, à medida que uma agência se expande e se consolida, fidelizando um grupo de empresas clientes e ampliando seu banco de demandantes de trabalho, pode passar a contratar diretamente parte desses trabalhadores para disponibilizá-los às empresas a que serve. Dessa sorte, a relação de serviço entre elas se torna mais duradoura e complexa, ultrapassando o mero trabalho de localizar no mercado potenciais funcionários. O caminho nessa via de crescente complexidade segue, assim, o rumo da transição da condição de simples (agência de empregos) localizadora de contratados potenciais à de fornecedora regular de serviços de recrutamento e seleção de funcionários (uma consultoria de recursos humanos), e desta à de locadora e fornecedora de estoques de trabalho contratados (uma empresa de trabalho temporário e terceirizado). O interessante é verificar que, nesse curso, o movimento entre funções não suprime as mais simples à medida que agrega as mais complexas; é mais propriamente um movimento cumulativo. As trajetórias de várias das grandes firmas de intermediação no Brasil tende a se aproximar dessa primeira via.

Contudo, não é apenas o caminho de crescimento prévio e de bemsucedida diversificação que leva à ampliação do portfólio. Muitas vezes é a busca de nichos no mercado de intermediação, ou seja, é a focalização em itens do portfólio a estratégia para vir a promover a consolidação e o crescimento da agência, levando-a a conciliar a tarefa de circular informação com aquela outra, mais desafiadora, de formar estoques de trabalhadores especializados em ramos específicos do mercado, ofertando-os a possíveis empresas usuárias a fim de fidelizá-las. O provimento de trabalho no ramo de teleatendimento parece um bom exemplo dessa via de consolidação de negócios. 
Casos há também em que empresas fornecedoras de trabalho altamente qualificado já surgem como empresas de trabalho temporário, sem a necessidade de experiência prévia como agências de emprego. Esse percurso parece ser mais característico daquelas empresas que atuam em segmentos altamente especializados, de trabalho intensivo em conhecimento; nessas condições, um estoque de empregados presta serviços com regularidade a múltiplas empresas "tomadoras de serviço", para usar o jargão nativo presente entre os empresários do ramo e também na legislação brasileira sobre o trabalho temporário. É justamente nelas que a fronteira entre o provimento de pessoal e a prestação de serviço pode se tornar muito tênue, deixando entrever que alcançamos aquela zona cinzenta na qual já não sabemos onde termina a prestação de serviços de intermediação e onde começa a prestação de serviços produtivos. Creio que isso tem mais chance de ocorrer justamente entre as empresas altamente especializadas em trabalho temporário de elevada qualificação.

Finalmente, há também de se considerar, ao lado do porte, da escala de operação e da complexidade do mix de serviços produzidos, a diversidade de propriedade de capital e de enraizamento espacial desses agentes. De fato, eles envolvem empresas em rede de calibre internacional - como a Manpower, mas não somente essa no caso do mercado brasileiro -, junto às quais se perfilam grandes empresas nacionais fortemente diversificadas em termos espaciais, inclusive na rota de se expandir internacionalmente, como é o caso da Gelre. Contudo, ao lado dessas, o mercado reserva espaço também para aqueles intermediadores privados, de médio e pequeno portes, dispostos em agências unilocalizadas, isoladas ou conglomeradas em condomínios. Por certo, seria impossível entender a diversidade do portfólio de serviços veiculados se não fosse levada em conta a diferença de escala de atuação. Tipo de ocupação intermediada, redes de captura e fidelização (tanto de demandantes quanto de empresas clientes), tamanho e perfil do quadro técnico, formas de gestão de seu trabalho e mecanismos utilizados para veicular a informação sobre vagas e demandantes, todas essas características variam conforme o porte, a escala de operação e as formas de enraizamento espacial.

Seria esse terceiro agente uma particularidade do mercado de força de trabalho? Nem de longe. Se considerarmos o moderno mercado de circulação da moeda, por exemplo, fica evidente o papel que nele jogam os intermediários financeiros. Talvez fosse possível dizer que, nesse 
caso, o coração do mercado pulsa justamente ali onde se localizam os serviços de intermediação (financeira). Se deixarmos o dinheiro e pensarmos as mercadorias em geral, veremos que desde sempre sua circulação dependeu de intermediários, que constituíram o que se entende por "comércio". De fato, o encontro entre produtores mercantis e consumidores passou a requerer um agente intermediador que tornasse os produtos acessíveis a quem os desejasse consumir.

No caso do trabalho, só mais recentemente os serviços de intermediação ganharam a importância que hoje têm nos grandes mercados capitalistas ${ }^{6}$. Echeverría (2001) destaca que foi apenas no pós-guerra que surgiram, inicialmente nos Estados Unidos e posteriormente na Europa, as primeiras empresas dedicadas a fornecer mão-de-obra - como mecanismos institucionalizados na operação do mercado de trabalhopara fazer face tanto às dificuldades de inserção dos retornados da guerra quanto às necessidades de provimento de trabalho para empresas em processo de reconversão produtiva com o declínio da produção bélica e a retomada de suas antigas linhas de produto.

Contudo, os contratos de prestação de serviços entre empresas locadoras e empresas usuárias conviveram por certo tempo com a figura das agências privadas de emprego, que cobravam diretamente dos demandantes pelo serviço de colocação que lhes prestavam. A regulamentação internacional tratou de banir esse tipo de conduta no marco regulatório internacional estabelecido pela OIT (Convênio 96 sobre Agências Pagas de Colocação). O crescimento importante dessas agências, porém, não foi capaz de elidir as tensões em torno de seu estatuto e de seus procedimentos ${ }^{7}$.

No Brasil, à diferença do que ocorreu nos Estados Unidos do pós-guerra e nos países da Europa Ocidental em seguida, as empresas de trabalho temporário encontraram seu nicho constitutivo não na demanda do setor empresarial, mas no atendimento a necessidades de pessoal por parte do governo. Pressionado pelo controle sobre os gastos com a máquina administrativa que se segue ao golpe militar de 1964 e visando garantir a expansão de atividades burocráticas sem honrar o que era visto como as "regalias" de que desfrutavam então os funcionários públicos, o Executivo volta-se crescentemente para a terceirização, argüindo o alvo de maior eficiência dos novos contratados (Bicev, 2007).

Não por acaso, data desse período a legislação que regulamenta o funcionamento do setor, a Lei no 6.019, assinada pelo general Emílio Gar- 
rastazu Médici em 3 de janeiro de 1974 e poucos meses depois regulamentada através do Decreto no 73.841, também assinado por ele, em 13 de março do mesmo ano ${ }^{8}$. A máquina administrativa, contudo, necessitava de pessoal de forma duradoura, e os contratos não podiam exceder o período de três meses, sob pena de se configurar vínculo administrativo. Na disputa por direitos entre trabalhadores que demandavam regularização de vínculo e contratantes pouco dispostos a fazê-lo, a justiça brasileira, através do Tribunal Superior do Trabalho - TST, decide criando norma. Por meio do Enunciado no 331, o TST torna legal a prática que denomina "locação de mão-de-obra", reconhecendo, por essa via, contratos temporários de mais longa duração sob a forma de prestação de serviços entre agentes com vistas ao fornecimento de trabalhadores terceirizados. É desse momento também a constituição da organização coletiva dos empresários do setor, pela Associação Brasileira das Empresas de Serviços Terceirizáveis e de Trabalho Temporário - Asserttem, constituída em 17 de março de 1970, a partir da arregimentação de donos de firmas nacionais fortemente mobilizados pela conquista da regulamentação da atividade.

Vê-se assim que desde cedo se distinguem duas possíveis vias de incorporação do trabalho temporário. Na primeira dessas vias estava o trabalho temporário de curta duração, que se adequava ao instituto da legislação original e era contratado por prazo restrito, seja diretamente pela empresa ou órgão usuário, seja pelo intermediário. Na segunda, aquele de mais longo prazo, chamado de "trabalho terceirizado", contratado de modo mais duradouro por meio de empresas de intermediação e alocado nas empresas clientes com ônus e sob responsabilidade das primeiras. Na senda dessa diferença, vê-se como estava aberto o caminho para o florescimento das atividades de agenciamento e seleção e para o crescimento das atividades de locação propriamente dita.

Nas décadas de 1970 e 1980, pouco a pouco as empresas privadas, notadamente as multinacionais, mas também as grandes empresas nacionais que experimentavam crescimento mais significativo - como no setor de construção civil -, passam a aderir ao uso desses mecanismos para ampliar seus efetivos. $\mathrm{O}$ trabalho industrial e relativamente pouco qualificado dava o tom no recrutamento. Nos anos 1990, os serviços, sobretudo os mais modernos - bancos e intermediação financeira, teleatendimento, entre outros -, passam a constituir o filão para o setor de intermediação de mão-de-obra, se o observarmos pelo lado da deman- 
da de força de trabalho. O trabalhador jovem se torna seu grande cliente, considerando o lado da oferta de força de trabalho.

Os anos 1970, contudo, foram também decisivos para assentar as bases de outra parte do mercado de mão-de-obra no Brasil: aquele formado pelos agentes de intermediação mantidos pelo recurso público. Pouco mais de um ano depois da regulamentação do trabalho temporário, o regime militar institui o Sistema Nacional de Emprego - Sine, por meio do Decreto no 76.403, de 8 de outubro de 1975, como conseqüência da ratificação, pelo Brasil, da Convenção no 88 da OIT, que trata da organização do Serviço Público de Emprego.

A principal finalidade do Sine, na época de sua criação, era promover a intermediação de mão-de-obra instalando serviços e agências de colocação em todo o país. Além disso, previa o desenvolvimento de uma série de ações relacionadas a essa finalidade principal, tais como organizar um sistema de informações sobre o mercado de trabalho e fornecer subsídios ao sistema educacional e de formação de mão-de-obra para elaboração de suas programações. Para bem entender esse esforço regulador, porém, deve-se atentar para o fato de que tal institucionalização vinha no bojo de um período de florescimento da atividade econômica, quando oportunidades ocupacionais se haviam expandido na esteira do chamado "milagre econômico", cuja crise apenas se esboçava em 1975, momento em que essas novas iniciativas se institucionalizavam. De fato, elas parecem mais próprias a dar conta de um mercado em expansão, recorrendo a formas mais flexíveis de trabalho, cujas relações contratuais buscavam contornar direitos estabelecidos, herança do projeto de inclusão e extensão de cidadania do período populista. No que respeita aos chamados "postos de atendimento" do Sine, eles seriam instalados em vários pontos do país, embora ainda limitados por sua cobertura geográfica - circunscritos que estavam às capitais - e pela porção do mercado que alcançavam, notadamente o trabalho menos qualificado, em especial o serviço doméstico.

A feição atual do segmento público da intermediação só se estabeleceria com a crise de crescimento aguda que se faz sentir nos anos 1980 e 1990. Assim, em 1988, o art. 239 da Constituição Federal cria o Programa do Seguro-Desemprego, regulamentado posteriormente pela Lei no 7.998, de 11 de janeiro de 1990, que também instituiu o Fundo de Amparo ao Trabalhador-FAT. A partir dos anos 1990, alteram-se a natureza e a escala dos recursos para custeio e investimento do Sine, que 
passam a ser provenientes do FAT, por intermédio do Programa do Seguro-Desemprego. Do mesmo modo, já sob a égide da redemocratização, as normas e diretrizes de atuação do Sine passam a ser definidas pelo Ministério do Trabalho e Emprego - MTE e por um conselho tripartite, com presença de trabalhadores, empresários e governos, o Conselho Deliberativo do FAT - Codefat.

O desafio da conjuntura já era outro. Ganha importância a ação do governo no que ele próprio classifica como "intermediação de mão-deobra", no afã de

[...] (re)colocar o trabalhador no mercado de trabalho, [...] realizar cruzamento da necessidade de preenchimento de um posto de trabalho com a de um trabalhador que procura por uma colocação no mercado de trabalho [...], [visando] reduzir o desemprego friccional, contribuindo para que os postos de trabalho vagos não sejam extintos ou que não venha a ocorrer agregação de ocupação por dificuldades no preenchimento da vaga ${ }^{9}$.

A arquitetura institucional deixava claro o objetivo: “[...] o Sistema Nacional de Emprego dispõe de informações acerca das exigências dos empregadores ao disponibilizarem suas vagas junto aos postos de atendimento do SINE. Busca-se, dessa forma, a redução dos custos e do tempo de espera tanto para o trabalhador, quanto para o empregador"10.

Vários aspectos chamam a atenção na maneira pela qual o texto oficial enuncia os objetivos da ação de intermediação pelo sistema governamental e deixa entrever seus alvos. A temática do desemprego é agora o desafio explícito a enfrentar: a atuação pública quer reduzi-lo acreditando poder atuar sobre sua forma, que se entendia como apenas friccional. No entanto, o fantasma da recorrência do desemprego parece ficar reconhecido no enunciado sobre o alvo de "(re)colocar", que tanto pode conotar duas linhas de intervenção (em face dos primodemandantes e dos desempregados) quanto o esforço por colocar e recolocar, incessantemente, o trabalhador no mercado.

Outro aspecto importante da arquitetura do sistema que se consolida nos anos 2000 diz respeito à diversificação de agentes. As mesmas complexidade e diferenciação que salientei ao descrever o segmento da intermediação movido pelo recurso privado também podem ser reconhecidas no que concerne ao segmento movido pelo recurso público 
do FAT. À diferença do que fora o Sine em sua primeira fase de existência durante o período da ditadura militar, nos governos da redemocratização, particularmente no governo Fernando Henrique Cardoso, consolidam-se as experiências de gestão tripartite de fundos públicos (como notado anteriormente, do FAT inclusive), que vão ser a pedra de toque para dar acesso a agentes não-governamentais, como sindicatos e centrais sindicais, ao mundo dos intermediários no mercado de trabalho.

De fato, sindicatos e centrais ingressam na gestão e na execução de políticas públicas pela porta da qualificação profissional, por meio da experiência do Plano Nacional de Qualificação do Trabalhador - Planfor, concebido em 1995 e implementado a partir de 1996, também com recursos do FAT (Guimarães, Comin e Leite, 2000). Das ações em qualificação passam, em seguida, a atuar também na intermediação de empregos, consolidando-se, juntamente com os postos de atendimento do governo, como grandes intermediários no curso dos anos 2000.

Desse modo, foi formada a malha não-desprezível de agentes que se encontra hoje instalada nos grandes centros urbanos brasileiros, constituindo um verdadeiro mercado de intermediação de oportunidades ocupacionais. De um lado estão as agências privadas de emprego, as consultorias de recursos humanos e as empresas de trabalho temporário; de outro, vê-se uma rede de postos de intermediação mantida pelo recurso público e gerenciada algumas vezes diretamente pelo próprio governo, mas muitas vezes, indiretamente, por entidades ligadas ao movimento sindical (sindicatos e confederações), a instituições religiosas (especialmente a Igreja Católica) e a movimentos sociais organizados por organizações não-governamentais.

Como opera essa malha de agentes? Para melhor responder a essa indagação, nada como focalizar um caso empírico denso. Esse é o objetivo da seção seguinte. Nela são analisados achados de uma pesquisa que vem sendo conduzida na Região Metropolitana de São Paulo, principal mercado de trabalho brasileiro e que reúne a maior concentração de intermediários. A observação privilegia o período que se localiza a partir dos anos 1990, focalizando a região justamente no momento em que esteve sujeita a intensa reestruturação econômica, sob taxas recordes de desemprego, mas que foi também um momento em que surgiram iniciativas governamentais de consolidação de um sistema público de emprego que contemplava nova forma de institucionalizar a po- 
lítica para o desemprego, constituindo mecanismos de proteção ao desempregado e de suporte à procura de trabalho.

\section{O MERCADO DE INTERMEDIAÇÃO DE EMPREGOS: UMA CONSTRUÇÃO TERRITORIALIZADA}

O ponto de partida desta terceira seção é a convicção teórica de que, para bem entendermos a construção social do mercado de intermediação de oportunidades de trabalho, temos de observá-lo em suas formas específicas de enraizamento espacial. Nesse sentido, a análise de um caso tem dupla utilidade. De um lado permite dar concreção aos vários agentes de intermediação de que tratei anteriormente sob forma ainda abstrata. De outro, e é o que mais importa nesta seção, permite evidenciar os arranjos econômicos que se estabelecem em um dado território e, assim, avançar em direção a identificar outros agentes a fim de bem descrever como operam segmentos particulares do mercado de trabalho.

Em outra oportunidade (Guimarães, 2004), argüi que, nos anos 1990, a metrópole paulista se consolidou como um verdadeiro mercado de intermediação, estando ali instaladas todas as figuras-chave para esse mercado de serviços. Por quê? Do ponto de vista dos demandantes de trabalho, o novo padrão de transições ocupacionais, intensas e pautadas por um desemprego recorrente, encarregou-se de prover, em escala notável, os indivíduos potencialmente agenciáveis (idem, 2006). Digo potencialmente porque, como também foi documentado em outra oportunidade (Guimarães et alii, 2004), para uma parcela significativa dessas pessoas, a procura de trabalho escapava à forma mercantil, resolvendo-se, no mais das vezes, por meio de redes sociais enraizadas no mundo de suas relações interpessoais, com elos mais ou menos fortes.

Já do ponto de vista dos intermediadores, foi também nos anos 1990 que floresceu o negócio do trabalho temporário em São Paulo. As firmas (chamadas por nossas estatísticas de "empresas de agenciamento, locação e intermediação de mão-de-obra") proliferaram no período, estabelecendo-se nesse mercado potencial e crescendo de maneira igualmente notável nessa década. Tal crescimento constitui uma faceta ainda pouco estudada do processo de reestruturação microorganizacional por que passaram as empresas brasileiras. No curso do movimento de focalização de sua atividade produtiva, elas externalizaram algumas das tarefas de gestão do pessoal até então habitualmente exercidas por seus departamentos de recursos humanos; a principal delas, 
a de triagem de potenciais recrutados. As novas empresas de intermediação passaram, então, a se encarregar da captura do demandante, orientando-o em suas formas de procura no circuito mercantil. Nutria-se, assim, o negócio da intermediação.

Tal atividade se tornou estratégica em uma conjuntura de enxugamento de postos de trabalho e de crescente desemprego. Isto é, dada a escala em que a procura de trabalho se exprimia em São Paulo nos anos 1990, deixava de ser trivial o processo de recrutar, haja vista o investimento requerido em termos de tempo e de trabalho; para as novas (e poucas) vagas então abertas apresentavam-se verdadeiros exércitos de pleiteantes. Aos intermediários cabia realizar a filtragem inicial, reduzindo o leque de alternativas a um pequeno grupo de poucos (e bons) candidatos, que seriam finalmente avaliados pelos gestores de recursos humanos sediados na firma contratante. Não sem razão, já em 2001, pude verificar que um terço dos indivíduos entrevistados em uma amostra representativa dos ativos de 16 anos ou mais, na Região Metropolitana de São Paulo, referia, entre seus mecanismos habituais de procura de trabalho, o recurso às empresas privadas de intermediação e agenciamento de colocações (ibidem; Guimarães, 2006).

Tomando como exemplo a região do chamado $\mathrm{ABC}$ Paulista, coração da atividade industrial na Região Metropolitana e palco do mais significativo enxugamento de empregos nesse período (Cardoso, 2000), estudo realizado entre as empresas de intermediação de trabalho ali atuantes, em 2002, mostrou a sincronia existente entre a intensificação da chegada desses intermediadores e a intensificação do processo de reestruturação das firmas na região ${ }^{11}$. Tal sincronia fica evidente no Gráfico 1 a seguir: nada menos que $60 \%$ das empresas privadas de intermediação que operavam no $\mathrm{ABC}$ em 2002 haviam sido fundadas a partir de 1995; quase três quartos delas se haviam estabelecido no curso dos anos 1990.

Mais ainda: georreferenciando os dados relativos à localização dessas empresas no Estado de São Paulo ${ }^{12}$, vê-se que é na Região Metropolitana que está concentrada sua parcela mais importante. Nesta, a distribuição se faz em alguns aglomerados, que sugerem a provável existência de clusters de intermediadores, identificáveis no mapa contido na Figura 1.

Conquanto São Paulo seja a região do Brasil que mais concentra os inscritos e as vagas no sistema público de intermediação, a Figura 2 deixa 


\section{Gráfico 1}

As Empresas de Intermediação de Trabalho na Região Metropolitana de São Paulo: A Sincronia entre Chegada dos Agentes e Reestruturação das Firmas

O Exemplo do ABC (2000)

Distribuição das unidades locais do Grupo 745 da Região do Grande ABC Paulista segundo faixas do ano de fundação da empresa (2000)

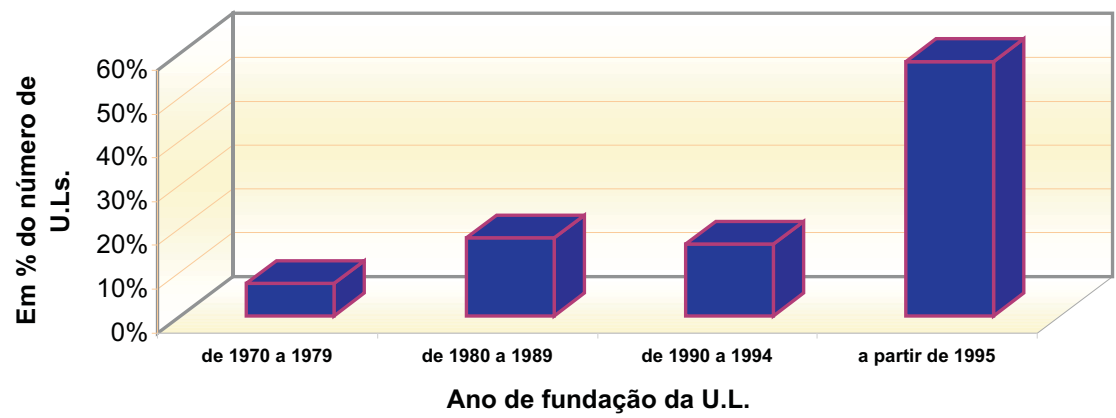

Fonte: Pesquisa da Atividade do Setor de Serviços Empresariais do Grande ABC - PASSE/ABC apud Pamplona (2003).

entrever quão menor é a densidade espacial dos intermediadores públicos (postos de intermediação de emprego e agências mantidas pelo recurso do FAT) quando comparados à densa rede de intermediadores privados (agências privadas de emprego e empresas de trabalho temporário) retratada na Figura 1.

Os dados até aqui apresentados sugerem que o mercado de intermediação requer uma escala mínima para sua constituição. Por isso, seu enraizamento em um território reflete o grau de concentração com que demandantes e ofertantes se apresentam no mercado de trabalho.

Outra importante característica dos serviços de intermediação de oportunidades ocupacionais diz respeito ao fato de que essa sua escala de operação ganha concreção de modo complexo e heterogêneo por meio de uma pluralidade de agentes e de relações sociais de trabalho. Para melhor documentar esse aspecto, o trabalho de observação empírica voltou-se, entre 2005 e 2006, para analisar em maior profundidade os dois aglomerados que mais concentravam intermediadores, privados e públicos, e para os quais afluíam os maiores contingentes de demandantes na Grande São Paulo - as áreas de Santo Amaro e do Centro - , recentemente transformados em verdadeiros territórios de intermediação. Ademais, dada a escala com que ali se concentravam, os inter- 
Figura 1

Empresas Privadas de Intermediação de Trabalho na

Região Metropolitana de São Paulo (2002)

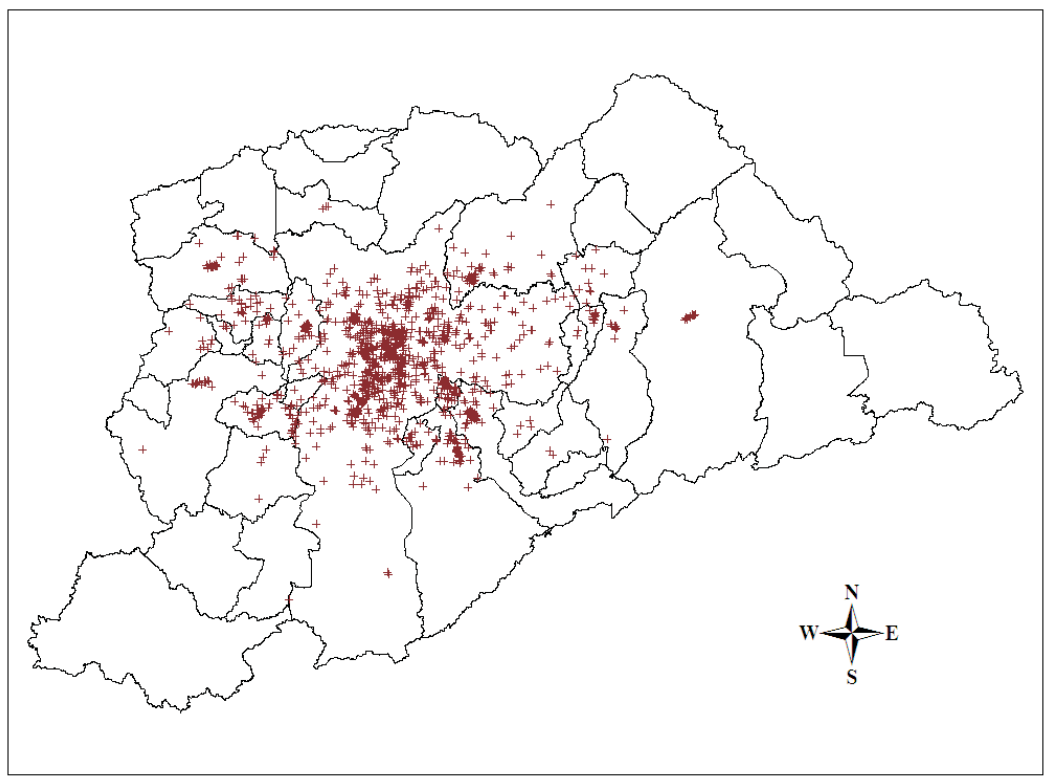

Fonte: Cadastro de Empresas, Relação Anual de Informações Sociais / Cadastro Geral de Empregados e Desempregados - Rais /Caged (2002). Processamento próprio (ver Guimarães, 2004).

mediadores dessas duas localidades atraíam tanto demandantes dos respectivos bairros e adjacências quanto do município (caso de Santo Amaro), e mesmo de outras cidades da Região Metropolitana (caso do Centro).

A análise dos bancos de dados governamentais sobre o perfil de quem acorre a suas agências nesses dois locais revela que se tratava de demandantes de emprego com menor qualificação. Além disso, tal como observado em survey realizado em agências de emprego em 2004, eles eram significativamente mais jovens que a média dos que buscavam trabalho na metrópole paulista (Guimarães, 2004). Essas duas características permitem entender por que surge ali uma nova gama de serviços especializados, conexos à procura de trabalho e de suporte para efetivação da intermediação. Novos atores ganhavam, assim, visibilidade, como resultado das observações realizadas nesses dois territó- 
Figura 2

Distribuição das Agências Governamentais e Sindicais na

Região Metropolitana de São Paulo (2003)

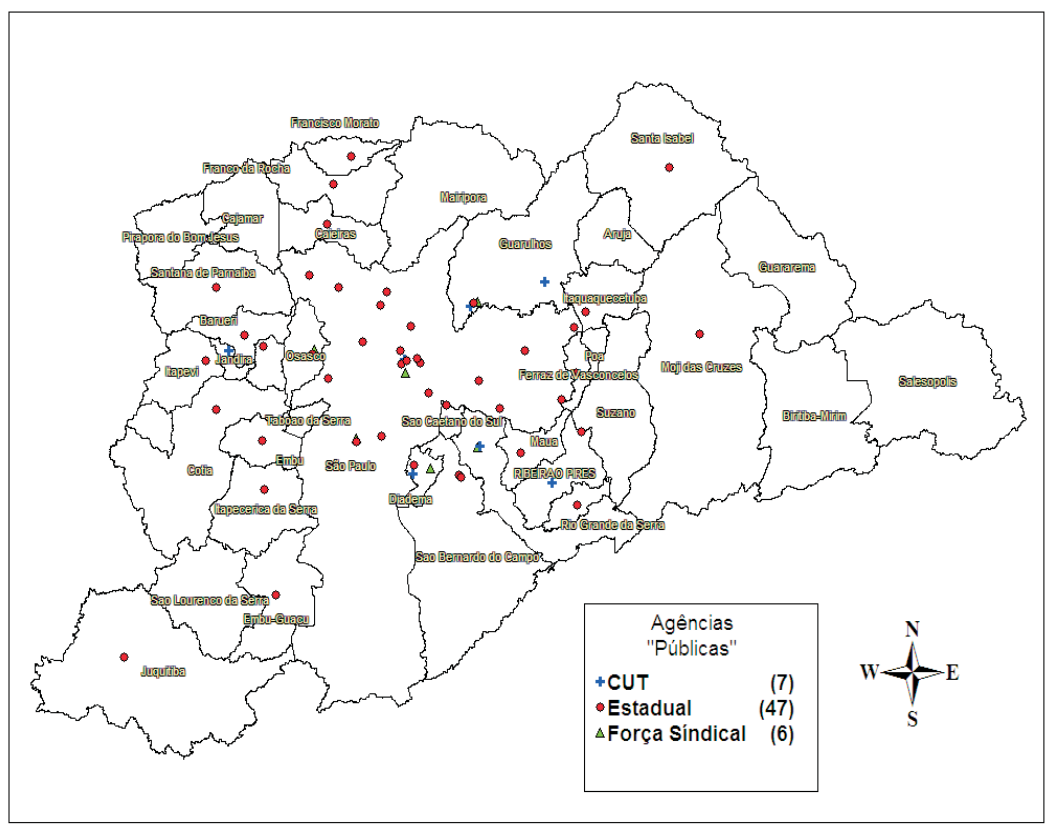

Fonte: MTE, Intermediação de Mão-de-Obra - IMO. Dados para 2003. Processamento próprio (ver Guimarães, 2004).

rios de intermediação. Quem eram eles e que tipo de serviço proviam? Vejamos em seguida.

Uma parte era representativa de um primeiro tipo de serviços cuja especialidade é, por assim dizer, "produzir a demanda", ou seja, transformar "indivíduos necessitados de trabalho" em "verdadeiros demandantes de emprego" (Guimarães, 2008). A esses negociantes cabe dotar as pessoas das características imprescindíveis à sua performance, enquanto demandantes de trabalho, para a adequada apresentação de si como um "merecedor de uma oportunidade ocupacional", notadamente aos olhos do intermediário privado. Alguns desses serviços são gratuitamente providos pelo próprio governo em seus boxes de atendimento; é o caso da documentação profissional (carteira de trabalho) ${ }^{13}$. Outros são providos por agentes privados: como aqueles que confeccionam (e reproduzem) o principal instrumento formal de apre- 
sentação de si, o currículo do demandante de trabalho (Hirano, 2007). Agentes privados também proviam outros documentos importantes e freqüentemente requeridos, como o atestado médico. Finalmente, uma terceira ordem de serviços conexos ao desemprego e à procura de trabalho se constitui ao redor do adiantamento dos valores que se pensa poder vir a receber do programa de seguro-desemprego. Ilegal, trata-se de antecipação de um benefício, na forma de empréstimo, promovida por quem não tem qualquer responsabilidade sobre sua concessão; empréstimos (provavelmente embutindo juros leoninos) sobre valores que o demandante de trabalho crê poder vir a receber. Todavia, o adiantamento do seguro é, muitas vezes, condição para seguir procurando trabalho. Ainda na fronteira da ilegalidade operam outros agentes privados, produzindo as tão almejadas credenciais de qualificação (diplomas de curso supletivo, por exemplo).

Um segundo tipo de serviços, igualmente próximo das necessidades de quem procura, conquanto mais especializado e profissional, era constituído pelos escritórios de advocacia trabalhista e cursinhos de treinamento profissional.

Ao lado desse rol de serviços conexos que preparavam o demandante, chamava a atenção, especialmente no Centro, a enorme diversidade de formas de veicular a informação sobre as oportunidades de trabalho. Por certo, parte substancial dessa veiculação se faz nas próprias agências de emprego, seja em seu interior, seja em quadros fixados à entrada. No entanto - e isso também resultou da observação sobre o modo como operam os agentes em situações concretas, territorializadas, de procura -, parte importante da veiculação das oportunidades ocupacionais, notadamente nas agências de pequeno porte, faz-se através dos braços móveis dessas firmas: os "plaqueiros" ou os "homens-placa" (Vieira, 2007).

Sua presença nos remete a outra dimensão interessante na análise do tema: a diversidade das relações de trabalho estabelecidas na execução do serviço de intermediação. Os "plaqueiros" (o masculino não é casual nem uma forma genérica) são trabalhadores empregados pelas agências (como o são as recepcionistas e as selecionadoras, e o feminino aqui tampouco é casual); são ambulantes que usam o próprio corpo para veicular os anúncios. Trabalhadores "invisíveis", se observarmos o modo como se relacionam com os ansiosos demandantes de trabalho, fazem circular, de maneira inusitada, a mercadoria-chave para esse 
mercado, qual seja, a informação sobre oportunidade de trabalho. Exercem sua atividade sob relações de trabalho que muitas vezes podem ser de longa duração (cinco ou dez anos). Todavia, embora duradouro, esse trabalho não supõe continuidade - podendo ser acionado em momentos de maior animação no setor -, muito menos formalização e proteção (ou direitos), conquanto os que ali se empregam sejam, em sua maioria, pessoas idosas. Exatamente por isso, vários se disseram aposentados ou inativos quando livres das "placas" que portavam ${ }^{14}$.

Esse tipo de trabalho complementa aquele que se desenvolve dentro da agência, na qual outros trabalhadores se mobilizam. Algumas vezes o alvo de sua atividade é o demandante de trabalho. É o caso da atuação das recepcionistas (normalmente moças e jovens), encarregadas do recebimento dos currículos, da triagem inicial e da armazenagem dos que parecem merecedores de convocação pela agência. Quando isso ocorre, mobiliza-se o trabalho das selecionadoras (em geral trabalhadoras de mais idade e/ou qualificação profissional e/ou responsabilidade gerencial), que atuam na retaguarda (habitualmente invisível) da agência, sendo responsáveis pelas entrevistas e/ou dinâmicas de gru$\mathrm{po}^{15}$. Contudo, com muita freqüência, a atividade no interior da agência volta-se para atender (ou capturar) a empresa cliente: contatos telefônicos para localização de novos clientes, para encaminhamento de candidatos potencialmente recrutáveis ou para (r)estabelecimento das relações comerciais com os tomadores de serviços. Nesse trabalho, homens e mulheres são mobilizados; ambos tendem a ter mais idade, responsabilidade na firma e/ou experiência/qualificação profissional. Quanto mais bem-sucedida a firma, mais complexa sua retaguarda, assim como mais variados seus clientes e mais diversificados e refinados os mecanismos pelos quais ela acessa os demandantes de trabalho e os relaciona com os ofertantes de vagas. Os sites de procura virtual dão uma boa medida de tais complexidade e diversidade.

A descrição anterior permite vislumbrar uma terceira característica. Além de ser um serviço movido à elevada escala de operação, que se territorializa e produz uma gama de relações sociais de trabalho, pode-se arriscar outra hipótese: esses conglomerados de intermediários, mais do que meros aglomerados, devem ser entendidos como verdadeiros clusters voltados ao serviço de intermediação. Algumas características inicialmente observadas parecem dar sustentação a tal hipótese, a saber: 
1) Tal como documentado anteriormente, são grandes a diversidade e a intercomplementaridade de funções entre os tipos de agente. Longe de mera justaposição, a interdependência entre os múltiplos tipos e funções de empreendedores aponta para a existência de um tecido econômico complexo e articulado.

2) Nesse sentido, foi possível observar a existência de cooperação entre as firmas intermediadoras, que assumem formas capazes de articular tanto as agências privadas entre si quanto estas com respeito às agências mantidas com recurso público (governamentais ou sindicais). Tal cooperação é movida pelo alvo comum de maximizar as colocações. Para as privadas, fazê-lo é condição para manter a relação de serviço com o cliente contratante; para as públicas, é condição para manter o fluxo do recurso do FAT, programa governamental que subsidia sua atuação e aloca verbas acompanhando-lhes a produtividade, medida por colocações efetuadas (isso ao menos era o que se passava no momento do trabalho de campo).

3) Tomando-se o ponto de vista do comportamento do demandante, é também possível reconhecer uma conduta que reforça a articulação entre os vários elementos que compõem o tecido local. Assim, em sua circulação, a fim de maximizar o tempo, ele multiplica os contatos com todos os intermediários possíveis, especialmente aqueles tidos como eficientes, imagem que ajuda a difundir. Por outro lado, em sua busca, reforça formas de cooperação com outros que também estão à procura de trabalho. Desse modo, apóiam-se reciprocamente no esforço por localizar novas agências, na montagem e partilha de roteiros para procura, na sugestão de iniciativas ou estratégias que podem ser eficazes para procurar trabalho.

Todavia, a articulação porventura existente nesses conglomerados de intermediadores não deve obscurecer o fato de que sua operação os distingue em pelo menos dois grupos principais: agências privadas e agências financiadas pelo recurso público (sejam elas governamentais, sejam sindicais). Por conseguinte, as situações de procura de trabalho variam quando observadas do ponto de vista de um ou outro grupo ${ }^{16}$.

Agências governamentais e sindicais, particularmente as primeiras, são muito bem-sucedidas em seu esforço por atrair e identificar aquele que necessita de trabalho. Por isso, entre os que são financiados pelo recurso público (FAT), há um notável ganho de qualidade com relação ao acesso e ao mapeamento dos demandantes. $\mathrm{O}$ mesmo pode ser dito 
com respeito aos modos de acolhida e ao tratamento conferido ao indivíduo em busca de trabalho. Ele se baseia em um elevado investimento em infra-estrutura, alavancado por um sistema de informação de excelente qualidade, que requer para sua operação um corpo de funcionários capacitados (tanto no manejo do sistema quanto na condução da entrevista para coleta de dados do demandante), além de espaço físico amplo e de investimentos diversos no layout das agências. Tudo isso assegura a recepção e o processamento das demandas dos desempregados em bases profissionais e tecnicamente refinadas. Algumas agências do circuito sindical haviam chegado, no momento do trabalho de campo, ao requinte de especializar espaços para acolher demandantes de nível universitário, a fim de ajudá-los a ultrapassar a vergonha associada não apenas à procura de emprego mas também às condições socialmente humilhantes em que, geralmente, essa procura se faz grandes filas, formadas de madrugada, em busca de senhas.

Entretanto, de muito pouco adiantavam os avanços nessa direção se eles não se complementavam com uma mobilização integrada das outras funções: a (re)qualificação e sobretudo a captura das vagas, esteios da chance de recolocação. Efetivamente, a rede de agências mantida com recurso público se mostrava tão bem organizada para mapear o demandante quanto mal aparelhada para localizar a vaga que poderia acolhê-lo.

Já os intermediários privados são movidos não tanto pelo intuito de fidelizar o demandante, mas sim pelo de fidelizar a empresa usuária, que contrata seus serviços para preencher vagas. Sua performance será tão mais bem-sucedida quanto maior for o número de empresas clientes e quanto mais rápida e eficiente for sua capacidade de encaminhar candidatos potencialmente recrutáveis ou de prover, com trabalhadores terceirizados ou subcontratados, a empresa "tomadora de seus serviços". A grande maioria desses intermediários, porém, notadamente os de pequeno e médio portes, faz baixíssimos investimentos no que concerne à captura de demandantes; estes lhes chegam por gravidade, dado o efeito inercial do grande e recorrente desemprego.

À primeira vista, tal diferença de comportamento empresarial poderia levar a uma relação de complementaridade entre agentes privados e públicos, já que um deles captura demandantes com eficiência enquanto o outro captura vagas com destreza. Na medida em que o critério para alocação do recurso público nas diversas unidades, governa- 
mentais e sindicais, tinha (ao menos até então) a eficácia na colocação como medida de sua eficiência - sendo o braço do sistema mantido pelo recurso público débil em sua capacidade de captura de vagas -, ele passa, para provê-las, a se valer das agências privadas, que, por sua vez, são débeis na captura de demandantes.

O leitor mais apressado já poderia argüir se não estaríamos diante de um caso potencialmente virtuoso, no qual poderia ser reconhecida uma cultura de "eficiência coletiva", correntemente tida como virtuosa nas análises de arranjos interfirmas. Entretanto, quando observamos o ponto de vista de cada um dos atores, isso não parece ser exatamente o que ocorre. De um lado as agências mantidas pelo FAT se ressentem de que os intermediários privados não lhes prestam contas do destino dado a "seus candidatos" (isto é, aos inscritos que lhes foram cedidos) depois que os alocam; sem isso eles não podem nutrir a contabilidade do êxito nos registros mensais que encaminham ao MTE e que lhes asseguram a continuidade do financiamento. Já as agências privadas se queixam da ineficiência da triagem por que passam os candidatos nas agências governamentais e sindicais, pondo em risco sua credibilidade em face da empresa usuária à qual encaminham tais candidatos, em geral pouco aderidos ao perfil por elas requerido, dado que haviam sido muito complacentemente selecionados pelos funcionários das agências públicas.

\section{CONSIDERAÇÕES FINAIS}

Pelo que até aqui se desenvolveu, quiçá tenha sido possível alinhar um rol de elementos que permite retornar à figura do triângulo, que expressa a especificidade do mercado de intermediação de oportunidades ocupacionais, com a densidade que só a riqueza da análise empírica permite.

Abri este artigo argüindo serem múltiplas as formas institucionais que convergiam para os três grandes pólos do triângulo que sintetiza uma nova tendência na organização do mercado de trabalho, especialmente nas grandes metrópoles; um mercado atravessado e de certo modo organizado pelo sistema de intermediação que se sustenta em três pólos. Vejamos cada um deles:

1) Pólo dos agentes que demandam emprego. Vimos que, se eles são trabalhadores, não necessariamente estão desempregados, ainda que majoritariamente o estejam. 
2) Pólo das firmas que se utilizarão do trabalho a ser recrutado no mercado. Vimos que não são necessariamente as firmas contratantes, dado o peso dos locadores atuantes no mercado de intermediação.

3) Pólo dos agentes que disponibilizam vagas no mercado, tornando-as visíveis, transparentes, para os demandantes, mas que também fazem o caminho de volta, triando trabalhadores potenciais. Vimos que esses agentes - centro do interesse neste texto - estão longe de ser simples recrutadores. Eles podem acumular um portfólio complexo e variado de atividades, bem como se apresentar sob um sem-número de formas, empresariais ou individuais, lícitas ou ilícitas, duradouras ou aventureiras, que fazem desse mundo um mar de diversidade.

A importância de considerar essas novas formas presentes no mercado de trabalho foi salientada na primeira seção deste artigo, recuperando recente literatura. À luz da observação do que tem ocorrido sobretudo nos países capitalistas mais avançados, essa literatura tem reiterado a estreita relação entre a consolidação de um mercado de serviços de intermediação, notadamente do negócio do trabalho intermediado e temporário, e o avanço no processo de fragilização dos vínculos de emprego em direção a novas formas e estatutos institucionais para o trabalho e sua contratualidade.

O que dizer, porém, de situações como a nossa, em que uma norma de emprego duradouro e protegido jamais se universalizou? Como, nessas situações, transcorre o processo de mercantilização da informação sobre oportunidades ocupacionais? Como entender a emergência de tal processo em um contexto social em que, pela ausência da proteção pública, é no espaço privado e por meio das redes interpessoais, notadamente familiares e de vizinhança, que o acesso à informação sobre chances de trabalho, para não dizer o acesso ao próprio trabalho, se resolve?

Na segunda seção, busquei retomar a trajetória de construção institucional do mercado de intermediação no Brasil a fim de mostrar os caminhos muito particulares pelos quais tal atividade emerge. Inicialmente foi estimulada pela demanda do Estado, significativamente do estado autoritário, cioso de quebrar a espinha do trabalho protegido no único nicho em que ele teimosamente resistia, no emprego público. Terceirizar atividades era o mecanismo para garantir a expansão da máquina gestora com independência de compromissos com respeito aos direitos dos trabalhadores que tivesse de empregar; movimento 
contrário ao que se verificara nos países capitalistas mais avançados e mais flexíveis no uso do trabalho, como nos Estados Unidos, onde foi pela demanda do setor privado que os intermediadores de mão-deobra se estabeleceram.

Contudo, em pouco menos de três décadas, a notável expansão do segmento denota os novos rumos que presidiram, entre nós, a ampliação de seus negócios. Eles foram alimentados, a partir dos anos 1990, por um duplo movimento. De um lado as firmas em reestruturação externalizam atividades, inclusive algumas no campo da gestão de recursos humanos. De outro, o enxugamento de postos faz saltar o desemprego, tornando o mercado de trabalho um espaço crescentemente opaco para os indivíduos em busca de emprego e fazendo, da tarefa de triar, um investimento organizacional considerável, pois as poucas vagas abertas passavam a atrair um sem-número de candidatos.

Na terceira seção, explorei, à luz dos dados para a Região Metropolitana de São Paulo, como transcorre esse processo e como nele se constitui uma complexa rede de intermediadores; diversos porque precisam fazer face a um mercado atraente por sua escala, mas no qual o desempregado precisa ser capacitado, simbólica e materialmente, para atuar como "um bom demandante" e "um competitivo candidato". A pobreza e a desigualdade sociais que marcam o cenário brasileiro deram régua e compasso para a proliferação de serviços e diversificação desse novo negócio, que passa a ter as formas que recobrem a ampla assimetria social brasileira, indo desde o precário serviço de preparo de currículo e o trabalho do "homem-placa" até os sites virtuais e as modernas empresas privadas de agenciamento e locação de mão-de-obra, algumas das quais já atuando em escala latino-americana.

No bojo desse movimento, estabeleceu-se o novo segmento dos intermediadores, no florescente tecido econômico dos serviços, notadamente nas grandes metrópoles; um verdadeiro mercado no interior do mercado de trabalho, forjado não apenas na esteira da reestruturação das firmas e da ampliação do desemprego mas também no vácuo de um sistema público de emprego e de um regime de bem-estar que assegurem proteção ao desempregado.

(Recebido para publicação em abril de 2007)

(Versão definitiva em novembro de 2007) 


\section{NOTAS}

1. É notório que me inspiro no argumento de Weber (1961) sobre o encanto da dinâmica dos mercados para a imaginação do sociólogo.

2. Espero demonstrar, adiante, que tal região constitui o principal mercado de intermediação de oportunidades de trabalho no caso brasileiro.

3. Região que está na origem do trabalho temporário nos Estados Unidos e onde se constituiu uma das empresas hoje emblemáticas do setor em escala internacional, a Manpower.

4. Por isso mesmo, as etnografias em locais de seleção passaram a ser estratégias de pesquisa de grande poder de fogo ao permitirem desvelar o modo como a relação entre agentes públicos de recrutamento, por um lado, e demandantes de trabalho, por outro, teciam suas relações na situação de entrevista e triagem nas agências. Elas evidenciaram como preconceitos e estereótipos tinham forte chance de se imiscuir, cerceando o acesso do demandante de trabalho à via de saída do desemprego (ver Benarrosh, 2000; 2005).

5. Muito embora essa regulamentação varie grandemente entre países e se caracterize por ser relativamente recente, difundindo-se nos anos 1990, como veremos adiante.

6. Pode-se argüir que intermediários no provimento de trabalho existiram anterior e episodicamente. Nesses contextos, eles foram tão mais centrais à organização econômica quanto mais opacos e segmentados fossem os mercados, e onde o provimento de trabalhadores se fizesse não pelo recrutamento de voluntários, mas sim pela coerção, muitas vezes física. Tal foi o caso dos antigos regimes escravistas ou das formas modernas de tráfico no chamado "trabalho escravo". Não sem razão, a Declaração da Filadélfia, de 1944, que constituiu a Organização Internacional do Trabalho-OIT, registra a recusa dos signatários a considerarem o trabalho uma mercadoria, banindo as agências de emprego da legalidade que então se instituía.

7. Basta lembrar o caso da Comunidade Européia (atual União Européia), por exemplo, na qual a primeira diretiva sobre o contencioso ao redor das agências privadas de trabalho temporário data de 1982 e, desde então, já vai quase um quarto de século de negociações delicadas.

8. A ausência de um marco regulador é reconhecida como o fator que frustrou a tentativa inicial da Manpower no sentido de penetrar no mercado de trabalho brasileiro. A empresa chega ao Brasil em 1963, mas retira-se em 1969, só retornando em 1978, quando o quadro normativo se completou, e ainda assim em associação com outro grupo.

9. Conforme site do MTE: www.mte.gov.br/imo/default.asp.

10. Idem.

11. Para outros detalhes sobre os resultados desse estudo, ver Pamplona (2003) e Guimarães (2004).

12. Tal georreferenciamento foi feito com base em dados do sistema Rais/Caged para o ano de 2002, atualizados a partir de outras informações ou bancos de dados tomados como mecanismos de controle, os mais importantes dos quais foram: o recadastramento dos intermediadores promovido pelo governo federal, as listas telefônicas, os 
anúncios classificados em jornais diários ou em panfletos especializados regularmente distribuídos na cidade.

13. Muito importante, inclusive, para explicar por que justamente os demandantes de menor idade acorrem em número relativamente maior às agências governamentais. Nelas não apenas se obtém a carteira de trabalho mas também a carteira de identidade, outro documento igualmente imprescindível, sem contar que nelas ainda se oferecia, na época, inscrição em programas voltados para os mais jovens.

14. Para uma descrição inicial bastante rica dessa figura e das relações sociais no quadro das quais emerge, ver Vieira (2007).

15. Para descrições mais detidas sobre o funcionamento de pequenas agências familiares ou de grandes organizações empresariais intermediadoras, ver, respectivamente, Georges e Janequine (2007) e Pedro (2007).

16. Em outra oportunidade (Guimarães, 2004), busquei sistematizar características que as diferenciariam. Para tal, combinei análise de dados quantitativos secundários (do Sistema Integrado de Gestão das Ações de Emprego - Sigae) e primários (de survey realizado em 2004 com demandantes em agências de emprego) com dados qualitativos (oriundos de observações iniciais dos cotidianos de um subgrupo de agências, retiradas dentre as amostradas no survey). 


\section{REFERÊNCIAS BIBLIOGRÁFICAS}

BECK, Ulrich e BECK-GERNSHEIM, Elisabeth. (2003), Individualization. London, Sage.

BENARROSH, Yolande (2000), “Tri des Chômeurs: Le Nécessaire Consensus des Acteurs de l'Emploi. Vers une Approche des 'Trappes d'Inemployabilité'”. Travail et Emploi, no 81, pp. 9-26.

BENNER, Chris, LEETE, Laura e PASTOR, Manuel. (2007), Staircases or Treadmills? Labor Market Intermediaries and Economic Opportunity in a Changing Economy. New York, Russell Sage Foundation.

(2005), Traitement des Chômeurs: Discours Institutionnel, Practiques des Acteurs. Paris, Centre d'Etudes de l'Emploi. Manuscrito.

BERGSTRÖM, Ola e STORRIE, Donald (eds.). (2003), Contingent Employment in Europe and the United States. Cheltenham, Edward Elgar.

BEYNON, Huw et alii. (2002), Managing Employment Change: The New Realities of Work. Oxford, Oxford University Press.

BICEV, Jonas Tomazi. (2007), A Constituição do Setor de Mão-de-Obra Temporária na Região Metropolitana de São Paulo, in N. A. Guimarães (org.), À Procura de Trabalho: Instituições de Intermediação e Redes Sociais na Saída do Desemprego. São Paulo, Centro de Estudos da Metrópole. Relatório final apresentado ao CNPq, pp. 131-146.

BOYER, Robert (ed.). (1988), The Search for Labour Market Flexibility: The European Economies in Transition. Oxford/New York, Oxford University Press/Clarendon Press.

BOYER, Robert e DURAND, Jean-Pierre. (1997), After Fordism. Houndmills/Basingstoke/ Hampshire, Macmillan.

CARDOSO, Adalberto Moreira. (2000), Trabalhar, Verbo Transitivo: Destinos Profissionais dos Deserdados da Indústria Automobilística. Rio de Janeiro, Editora FGV.

CONSONI, Flávia e BESSA, Vagner. (2007). Mecanismos Institucionalizados na Procura de Trabalho: Como se Configura o Mercado de Locação de Mão de Obra? Comunicação apresentada no V Congresso Latino-Americano de Sociologia do Trabalho, Montevidéu, 18-20 de abril.

DEGENNE, Alain e FORSÉ, Michel. (1994). Les Réseaux Sociaux. Paris, Armand Colin.

DEMAZIÈRE, Didier, GUIMARÃES, Nadya Araujo e SUGITA, Kurumi. (2006), “Unemployment, a Biographical Experience", in K. Kase e K. Sugita (eds.), The Unemployed and Unemployment in an International Perspective: Comparative Studies of Japan, France and Brazil. Tokyo, University of Tokyo, Institute of Social Sciences (ISS Research Series, vol. 19), pp. 42-67.

ECHEVERRÍA, Magdalena. (2001), “Condiciones de Trabajo en Sistema de Subcontratación”, in X. Díaz e E. Hola (orgs.), Trabajo, Flexibilidad y Género: Tensiones de un Proceso. Santiago, Centro de Estudios de la Mujer.

FLIGSTEIN, Neil. (1996), “Markets as Politics: A Political-Cultural Approach to Market Institutions". American Sociological Review, vol. 61, no 4, pp. 656-673.

FORDE, Chris. (2001), “Temporary Arrangements: The Activities of Employment Agencies in the UK". Work, Employment and Society, vol. 15, no 3, pp. 631-644. 
GALLIE, Duncan e PAUGAM, Serge. (2000), Welfare Regimes and the Experience of Unemployment in Europe. Oxford, Oxford University Press.

GARCIA-PARPET, Marie-France. (1986), “La Construction Sociale d'un Marché Parfait: Le Marché au Cadran de Fontaines-en-Sologne". Actes de la Recherche en Sciences Sociales, vol. 65 , pp. 3-15.

GEORGES, Isabel e JANEQUINE, Olívia G. (2007), Onde a Lei Pega? Etnografia de uma Agência Privada de Intermediação de Mão-de-Obra, in N. A. Guimarães (org.), À Procura de Trabalho: Instituições de Intermediação e Redes Sociais na Saída do Desemprego. São Paulo, Centro de Estudos da Metrópole. Relatório final apresentado ao CNPq, pp. 171-188.

GRANOVETTER, Mark S. (1973), "The Strength of Weak Ties". American Journal of Sociology, vol. 76, no 6, pp. 1361-1380.

. (1974), Getting a Job: A Study of Contacts and Careers. Cambridge, Harvard University Press.

(1985), "Economic Action and Social Structure: The Problem of Embeddedness". American Journal of Sociology, vol. 91, no 3, pp. 481-510.

(1991) [1988], "The Sociological and Economic Approaches to Labor Market Analysis: A Social Structural View", in M. Granovetter e R. Swedberg (eds.), The Sociology of Economic Life. Boulder, Westview Press, pp. 233-263.

GRAY, Anne. (2002), "Jobseekers and Gatekeepers: The Role of the Private Employment Agency in the Placement of the Unemployed". Work, Employment and Society, vol. 16, no 4, pp. 655-674.

GUIMARÃES, Nadya Araujo. (2004), O Sistema de Intermediação de Empregos: Um Outro Olhar sobre o Mercado de Trabalho em São Paulo. Relatório ao MTE/OIT e PMSP, São Paulo, Cebrap. Disponível em http://www.fflch.usp.br/sociologia/nadya/ sistema_intermediacao.pdf.

. (2006), “Trabalho em Transição: Uma Comparação entre São Paulo, Paris e Tóquio". Novos Estudos Cebrap, no 76, pp. 159-177.

. (2008), “À Procura de Trabalho: Desempregado, Demandante de Trabalho, Candidato". Revista Latinoamericana de Estúdios del Trabajo, ano 13, no 19, pp. 195-224.

GUIMARÃES, Nadya Araujo, COMIN, Álvaro e LEITE, Márcia. (2000), “Por um Jogo de Soma Positiva: Conciliando Competitividade e Proteção ao Emprego em Experiências Inovadoras de Negociação no Brasil", in N. A. Guimarães e S. Martin (orgs.), Competitividade e Desenvolvimento: Atores e Instituições Locais. São Paulo, Senac, pp. 417-448.

GUIMARÃES, Nadya Araujo e PICANÇO, Monise. (2007), Laços Fortes e Laços Fracos na Procura de Trabalho em São Paulo, in N. A. Guimarães (org.), À Procura de Trabalho: Instituições de Intermediação e Redes Sociais na Saída do Desemprego. São Paulo, Centro de Estudos da Metrópole. Relatório final apresentado ao CNPq, pp. 353-366.

GUIMARÃES, Nadya Araujo et alii. (2004), “Desemprego: Mercados, Instituições e Percepções. Brasil e Japão numa Perspectiva Comparada". Tempo Social, vol. 16, no 2, pp. 257-288. 
HIRANO, Luis Felipe. (2007), Currículo: Embalagem do Produto?, in N. A. Guimarães (org.), À Procura de Trabalho: Instituições de Intermediação e Redes Sociais na Saída do Desemprego. São Paulo, Centro de Estudos da Metrópole. Relatório final apresentado ao CNPq, pp. 189-228.

KARTCHEVSKY, André e CAIRE, Guy. (2000), Les Agences Privées de Placement et le Marché $d u$ Travail. Paris, L'Harmattan.

KOENE, Bas e PURCELL, Kate. (2004), The Value of Relationships in a Transactional Labour Market: Constructing a Market for Temporary Employment. Manuscrito.

MARX, Karl. (1985) [1887], El Capital: Crítica de la Economía Política. México, Fondo de Cultura Económica, livro I, cap. VI.

PAMPLONA, João Batista. (2003), Estudo das Empresas Prestadoras de Serviços de Seleção, Agenciamento e Locação de Mão-de-Obra Temporária do Grande ABC Paulista, in N. A. Guimarães et alii, Gestão Local, Empregabilidade e Eqüidade de Gênero e Raça: Um Experimento de Política Pública na Região do ABC Paulista. Relatório final, Fapesp/ Cebrap/Prefeitura Municipal de Santo André/Ceert/Elas. Disponível em http:/ / www.fflch.usp.br/sociologia/nadya.

PECK, Jamie e THEODORE, Nikolas. (1999), “O Trabalho Eventual: Crescimento e Reestruturação da Indústria de Empregos Temporários em Chicago". Revista Latinoamericana de Estudios del Trabajo, ano 5, no 10, pp. 135-160.

PEDRO, Mônica. (2007), A Intermediação de Mão-de-Obra numa Grande Organização: Especificidades de uma Empresa Pioneira. Documento de Trabalho, in N. A. Guimarães (org.), À Procura de Trabalho: Instituições de Intermediação e Redes Sociais na Saída do Desemprego. São Paulo, Centro de Estudos da Metrópole. Relatório final apresentado ao CNPq, pp. 148-170.

POLANYI, Karl. (2000) [1944], A Grande Transformação: As Origens da Nossa Época. Rio de Janeiro, Campus.

STEINER, Philippe. (1999), La Sociologie Économique. Paris, Éditions La Découverte.

__. (2004), Le Marché Vu par la Sociologie Économique. Lille, Université de Lille. Manuscrito.

SWEDBERG, Richard. (1994), "Markets as Social Structures", in N. Smelser e R. Swedberg (eds.), The Handbook of Economic Sociology. Princeton, Princeton University Press, pp. 255-282.

VIEIRA, Priscila F. (2007), O Homem e a Placa ou a Placa e o Homem? Os "Homens-Placa" e a Procura de Trabalho no Centro de São Paulo, in N. A. Guimarães (org.), À Procura de Trabalho: Instituições de Intermediação e Redes Sociais na Saída do Desemprego. São Paulo, Centro de Estudos da Metrópole. Relatório final apresentado ao CNPq, pp. 229-250.

WEBER, Max. (1961) [1922], Economía y Sociedad: Esbozo de Sociología Comprensiva. México, Fondo de Cultura Económica.

WHITE, Harrison C. (1970), "Matching, Vacancies, and Mobility”. Journal of Political Economy, vol. 78, no 1, pp. 97-105.

. (1981), “Where do Markets Come From?". American Journal of Sociology, vol. 87, no 3, pp. 517-587. 


\section{ABSTRACT \\ Labor as Enterprise: Employment Agencies as Obscurely Familiar Economic Middlemen}

A new economic sector has burgeoned in the wake of labor deregulation, especially in large metropolises: services specializing in the intermediation of work opportunities. Employment agencies, outsourcing and "temp" companies, and human resources consulting firms have formed a veritable market within the overall labor market. The article aims to analyze this market. The first section draws on the relevant international literature, systematizing the various analytical approaches. The second part conducts a historical analysis of how the job agency market was first established in Brazil. The third section analyzes how this market currently operates, based on the case of São Paulo, Brazil's largest metropolitan labor market in general and largest job agency market in particular. Micro-data for 2001 and 2004 from the RAIS (the official Annual Survey of Information and Salaries) and ethnographic observation in the largest cluster of job agencies provide the basis for the conclusions in the fourth and last section of the article.

Key words: work market; job intermediation; job flexibility; São Paulo; employment agencies

\section{RÉSUMÉ}

Gérer le Travail: Les Agents Économiques Médiateurs d'Emploi, ces Illustres Inconnus

À la suite de la flexibilité des relations dans l'emploi et surtout dans les grandes métropoles, un nouveau sécteur économique se développe, celui des services d'entremise des opportunités de travail. Il s'agit d'agences d'emplois, entreprises de sous-traitance et de traval temporaire, conseils en ressources humaines, qui forment un vrai marché dans le marché du travail. Dans cet article, on cherche à en faire l'analyse. Dans la première partie, on examine la littérature internationale sur le sujet, en traçant des voies pour l'analyse. Dans la deuxième, on remonte dans le temps pour voir comment s'est constitué au Brésil un marché de médiation de l'emploi. Dans la troisième, on examine comment opère ce marché, à la lumière du cas de São Paulo, le plus grand marché métropolitain du travail et de la médiation. Des micro-données de la RAIS, résultats de deux surveys (en 2001 et 2004) et de l'observation ethnographique menée dans leur plus grand groupe de médiateurs, contribuent aux conclusions de la quatrième et dernière partie du texte.

Mots-clé: marché du travail; entremise d'emplois; flexibilité; São Paulo; agences d'emploi 